\title{
EFECTOS DEL SUMNISTRO DE Lasalocid A VACAS LECHERAS BAJO CONDICIONES DE PASTOREO DE ALFALFA
}

\author{
Gallardo, M. R. ${ }^{1,2}$, MaizTegul, J. A. ${ }^{2}$, Valtorta, S. E. ${ }^{2,3}$, \\ Paolella, M. ${ }^{4}$, Lorenzón, M. M. ${ }^{1}$ \& Romano, G. S. $^{2}$
}

\begin{abstract}
RESUMEN
Con el objetivo de evaluar el efecto de diferentes dosis de Lasalocid sobre la producción y la composición química de la leche de vacas de alta producción, bajo condiciones pastoriles de Argentina se llevaron a cabo dos experimentos. Durante 1996 se utilizaron 36 vacas Holando argentino en primer tercio de lactancia y en 199748 vacas en inicio de lactancia y lactancia media. Los tratamientos del primer ensayo fueron: Control (Tc); 200 y $400 \mathrm{mg}$ de ionóforo (T200 y T400). En 1997 se tuvieron los grupos Tc; T200 y T300. Los resultados indicaron que la inclusión de al menos $300 \mathrm{mg}$ de Lasalocid a la dieta de vacas en lactancia temprana tendría un efecto positivo sobre la productividad en sistemas pastoriles, aún cuando la pastura represente un elevado porcentaje de la dieta. En ningún caso se vió afectada la calidad composicional de la leche.
\end{abstract}

Palabras clave: pastoreo de alfalfa, ionóforos, Lasalocid, producción y composición de leche.

\section{SUMMARY}

\section{Effects of supplying Lasalocid to dairy cows under alfalfa grazing condi- tions.}

Two trials were performed to evaluate the effect of different doses of Lasalocid on milk production and composition of high yielding cows under Argentine grazing conditions. Thirty six Dutch Argentine cows in first third of lactation were utilized during a trial carried out in 1996, while in 1997, 48 cows in early and mid lactation were used. The treatments for the first trial were: Control (Tc), 200 and $400 \mathrm{mg}$ Lasalocid (T200 and T400). In 1997, the treatments were: Tc; T200 and T300. The results indicated that including at least $300 \mathrm{mg}$ Lasalocid to the diet of cows in early lactation would produce a positive effect on productivity of grazing systems, even when pasture represents a high percentage of the diet. Milk composition was not affected in any case.

Key words: alfalfa grazing, ionophores, Lasalocid, milk production and composition.

\footnotetext{
1.- Instituto Nacional de Tecnología Agropecuaria - INTA EEA Rafaela. Ruta 34, km. 227, (2300) Rafaela, Santa Fe, Argentina.

2.- Facultad de Ciencias Veterinarias, Universidad Nacional del Litoral.

3.- Consejo Nacional de Investigaciones Científicas y Técnicas -CONICET, Argentina-.

4.- Roche S.A.Q.I. (Div. Vitaminas) Argentina.

Manuscrito recibido el 9 de abril de 2001 y aceptado para su publicación el 22 de marzo de 2002.
} 